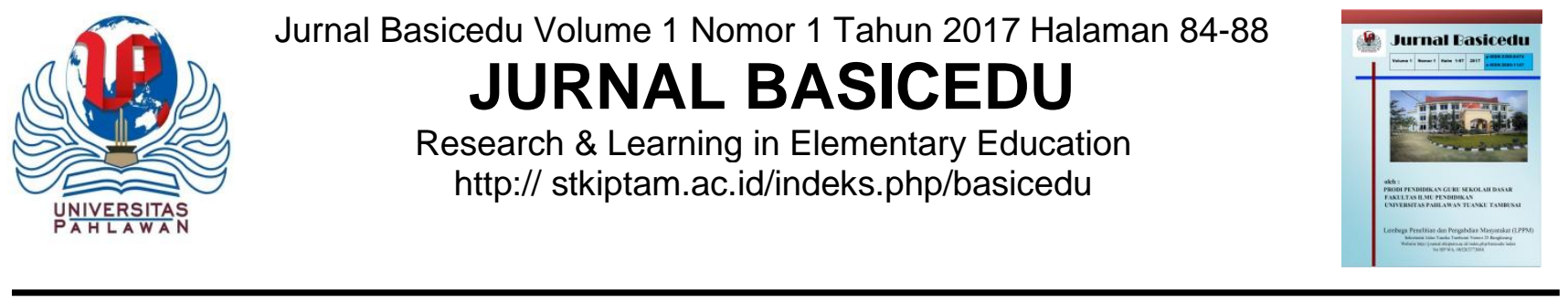

\title{
PENINGKATAN HASIL BELAJAR IPS DENGAN MODEL PEMBELAJARAN INKUIRI SISWA KELAS IV SD NEGERI 016 BANGKINANG KOTA
}

\author{
Mufarizuddin $^{1}$ \\ ${ }^{1}$ Fakultas Ilmu Pendidikan, Prodi PGSD Universitas Pahlawan Tuanku Tambusai \\ email : zuddin.unimed@gmail.com
}

\begin{abstract}
Classroom Action Research (CAR), which aims to increase the social studies in grade IV SDN 016 Bangkinang City with inquiry learning model application. This study was conducted in two cycles, with each cycle consisting of two meetings. The subjects were all students in fourth grade Bangkinang City State 016 Academic Year 2015/2016 totaling 20 students. The object of this research is the implementation of social studies learning by inquiry learning model application. The data in this study were obtained through observation of teaching practices, student activity sheet (LKS), the end of the test cycle and Interview. Research conducted on inquiry learning in the fourth grade students of SD Negeri 016 Bangkinang City through the stages as follows: 1) discovery, 2) percentage of class, 3) award groups. The study results indicated by the increasing student learning outcomes IPS from the first cycle to the second cycle. The results showed that the activity of students has increased from cycle I with percentage of $67.5 \%$ and the second cycle with a percentage of $90 \%$. Student learning outcomes also increased, namely in the first cycle, that the percentage of student learning outcomes reached $70.1 \%$, while on the second cycle increased with the acquisition of $84.9 \%$ percentage. Based on the research that the implementation of inquiry learning model can improve learning outcomes IPS Elementary School fourth grade students 016 Bangkinang City.
\end{abstract}

Keywords: social studies results, inquiry learning model.

\begin{abstract}
Abstrak
Penelitian Tindakan Kelas (PTK) yang bertujuan untuk meningkatkan hasil belajar IPS pada siswa kelas IV SD Negeri 016 Bangkinang Kota dengan penerapan model pembelajaran Inkuiri. Penelitian ini dilaksanakan dalam dua siklus, dengan masing-masing siklus terdiri dari dua pertemuan. Subjek penelitian ini adalah seluruh siswa kelas IV SD Negeri 016 Bangkinang Kota Tahun Ajaran 2015/2016 yang berjumlah 20 siswa. Objek penelitian ini adalah pelaksanaan pembelajaran IPS dengan penerapan model pembelajaran Inkuiri. Data dalam penelitian ini diperoleh melalui observasi pelaksanaan pembelajaran, lembar kegiatan siswa(LKS), tes akhir siklus dan wawacara.Penelitian yang dilakukan pada pembelajaran Inkuiri pada siswa kelas IV SD Negeri 016 Bangkinang Kota melalui tahap-tahap sebagai berikut: 1) penemuan, 2) persentase kelas, 3) penghargaan kelompok. Hasil belajar tersebut ditunjukkan dengan meningkatnya hasil belajar IPS siswa dari siklus I ke siklus II.Hasil penelitian menunjukkan bahwa keaktifan siswa mengalami peningkatan dari siklus I dengan persentase 67,5\% dan pada siklus II dengan persentase 90\%. Hasil belajar siswa juga mengalami peningkatan yaitu pada siklus I, bahwa hasil belajar siswa mencapai persentase $70.1 \%$ Sedangkan pada siklus II terjadi peningkatan dengan perolehan persentase $84.9 \%$. Berdasarkan hasil penelitian bahwa penerapan model pembelajaran Inkuiri dapat meningkatkan hasil belajar IPS siswa kelas IV SD Negeri 016 Bangkinang Kota.
\end{abstract}

Kata Kunci : Hasil belajar IPS, Model pembelajaran Inkuiri. 


\section{PENDAHULUAN}

Berdasarkan hasil pengamatan di Berdasarkan pengamatan yang dilakukan, masalah yang ada dilapangan rendahnya hasil belajar pada siswa kelas IVdi SD Negeri 016 Bangkinang Kota, ini dibuktikan dengan rendahnya hasil belajar IPS siswa pada tahun 2014/2015. Pada tahun 2015/2016 siswa berjumlah 20 orang yang terdiri dari 13 siswa perempuan dan 7 siswa laki-laki. Berdasarkan pengamatan dari keseluruhan hanya 8 orang siswa saja yang mampu memiliki nilai diatas KKM, sedangkan 12 orang siswa masih kurang dari (KKM) yaitu 70 .

Oleh sebab itu, penulis akan melakukan penelitian untuk meningkatkan hasil belajar murid melalui model pembelajaran Inkuiri. Dengan memperhatikan beberapa dasar permasalahan yang terjadi dan memperhatikan penjelasan para ahli mengenai model pembelajaran Inkuiri di atas maka penulis tertarik untuk mengadakan suatu penelitian. Adapun penelitian yang akan penulis lakukan adalah penelitian tindakan kelas dengan judul "Peningkatan Hasil Belajar IPS dengan Model Pembelajaran Inkuiri Siswa Kelas IV SD Negeri 016 Bangkinang Kota".

Model pembelajaran Inkuiriadalah suatu jenis teknik simulasi yang umumnya digunakan untuk pendidikan sosial dan hubungan antar insan.Teknik ini mengajak siswa untuk dapat mendramatisasikan tingkah laku atau ungkapan gerak-gerik wajah seseorang dalam hubungan sosial, Roestiyah (2001:90) mengemukakan metode Inkuiriadalah suatu jenis teknik simulasi yang umumnya digunakan untuk pendidikan sosial dan hubungan antar insan.Teknik ini mengajak siswa untuk dapat mendramatisasikan tingkah laku atau ungkapan gerak-gerik wajah seseorang dalam hubungan sosial antar manusia atau siswa bisa berperan atau memainkan peranan dalam dramatisasi masalah sosial atau psikologis.

Menurut Kunandar

(2007:349)

pembelajaran Inkuiri adalah pendekatan pembelajaran dimana siswa didorong untuk belajar melalui keterlibatan aktif mereka sendiri dengan konsep-konsep dan prinsip- prinsip, dan guru mendorong siswa untuk memiliki pengalaman dan melakukan percobaan yang memungkinkan siswa menemukan prinsip-prinsip untuk diri mereka sendiri. Hal senada juga dikemukakan oleh Roestiyah N.K. (2001:90) metode Inkuiriadalah suatu jenis teknik simulasi yang umumnya digunakan untuk pendidikan sosial dan hubungan antar insan.Teknik ini mengajak siswa untuk dapat mendramatisasikan tingkah laku atau ungkapan gerak-gerik wajah seseorang dalam hubungan sosial antar manusia atau siswa bisa berperan atau memainkan peranan dalam dramatisasi masalah sosial atau psikologis.

Roestiyah

(2001:76) mengemukakanbeberapa keunggulan teknik Inquiry antara lain:

a. Dapat membentuk dan mengembangkan "sels-consept" pada diri siswa, sehingga siswa dapat mengerti tentang konsep dasar dan ide-ide yang lebih baik.

b. Membantu dalam menggunakan ingatan dan transfer pada stuasi proses belajar yang baru.

c. Mendorong siswa untuk berfikir dan bekerja atas inisiatifnya sendiri, bersikap objektif, jujur dan terbuka.

d. Mendorong siswa untuk berfikir intuitif dan merumuskan hipotesanya sendiri.

e. Memberikan kepuasan yang besifat intrinsik.

f. Situasi proses belajar menjadi lebih merangsang

g. Dapat mengembangkan bakat atau kecakapan individu.

h. Memberikan kebebasan pada siswa untuk belajar sendiri

i. Siswa dapat menghindari siswa dari cara-cara belajar yang tradisional.

Langkah-Langkah Pelaksanaan Metode Inkuiri Sanjaya (2007:159-160) bahwa langkah-langkah metode Inkuiriadalah sebagai berikut:

a. Menetapkan topik atau masalah serta tujuan yang hendak dicapai Inkuiri. 
b. Guru memberikan gambaran masalah dalam situasi yang akan dimainkan.

c. Guru menetapkan pemain yang akan terlibat dalam Inkuiri, peranan yang harus dimainkan oleh para pemeran, serta waktu yang disediakan.

d. Gurumemberikan kesempatan kepada siswa untuk bertanya khususnya kepada siswa yang terlibat dalam pemeranan.

e. Inkuiri mulai dimainkan oleh kelompok pemeran.

f. Guru menarik perhatian siswa.

g. Guru hendaknya memberikan bantuan kepada pemeran yang mendapat kesulitan.

h. Inkuiri hendaknya dihentikan pada saat puncak. Hal ini dimaksudkan untuk mendorong siswa berpikir dalam menyelesaikan masalah yang sedang dimainkan

i. Melakukan diskusi tentang peran yang dimainkan.

\section{METODOLOGI PENELITIAN}

Model pembelajaran Inkuiri adalah suatu jenis teknik praktik pembelajaran yang mengajak siswa untuk dapat mendramatisasikan tingkah laku atau ungkapan gerak-gerik wajah seseorang dalam hubungan sosial antar manusia atau siswa bisa berperan atau memainkan peranan dalam dramatisasi kegiatan ekonomi atau psikologis.

Belajar adalah suatu proses usaha yang dilakukan individu untuk memperoleh suatu perubahan tingkah laku yang baru secara keseluruhan sebagai hasil pengalaman individu itu sendiri dalam interaksi dengan lingkungannya.

Penerapan dalam kamus bahasa Indonesia penerapan adalah pelaksanaan atau proses cara perbuatan menerapkan. Dalam penelitian ini penerapan adalah cara menerapan model pembelajaran Inkuiri di kelas.

Ilmu Pengetahuan Sosial (IPS) adalah ilmu yang memuat materi geografi, sejarah, sosiologi, dan ekonomi. Melalui mata pelajaran IPS, perserta didik diarahkan untuk dapat menjadi warga negara Indonsia yang demokratis, dan bertanggung jawab, serta warga dunia yang cinta damai.

Peningkatan hasil belajar peserta didikpada mata pelajaran Ilmu Pengetahuan Sosial (IPS) diperlukan suatu model dalam pembelajaran yang lebih komprehensif dan dapat mengaitkan materi teori.Dalam model Inquiry, peserta didikmencari pasangan sambil belajar mengenai suatu konsep atau topik dalam suasana yang menyenangkan. Peserta didikterlihat lebih bersemangat dan antusias dalam proses pembelajaran.Suatu model yang diterapkan seperti permainan namun mampu membuat aktif, kerja sama, mengingat dan merasakan secara langsung aktifitas-aktifitas yang mereka lakukan sendiri. Selain itu, ketika mencari pasangan dari kartu yang mereka dapat, juga secara langsung dapat belajar bersosialisasi dengan teman-teman sekelasnya, sehingga mengembangkan sifat sosial pada diri pesrta didik.Penerapan model Inquiry ini dapat memotivasi peserta didikdalam pembelajaran dan memberikan dampak yang positif untuk hasil belajar pesrta didik.

Bentuk penelitian ini adalah penelitian tindakan kelas (PTK). Menurut Arikunto (2008) penelitian tindakan kelas dapat diartikan sebagai suatu bentuk penelitian yang bersifat refelektif dengan melakukan tindakan tertentu, agar dapat memperbaiki praktek pembelajaran dikelasnya secara profesional. Tindakan yang akan dilakukan adalah penerapan model pembelajaran Inkuiri terbimbing dalam pembelajaran IPS. dikatakan Penelitian Tindakan Kelas Inkuiri karena pada penelitian ini pelaksanaan tindakan akan dilakukan oleh peneliti kelas IV SD Negeri 016 Bangkinang Kota, bertindak sebagai pengamat selama proses pembelajaran berlangsung.

Tindakan yang akan dilakukan dalam penelitian ini adalah penerapan model pembelajaran ingkuiri pada materi pokok kegiatan ekonomi untuk meningkatkan hasil belajar IPS siswa kelas IV SD Negeri 016 Bangkinang Kota. Adapun disain penelitian yang akan dilakukan pada penelitian kali ini terdapat dua siklus ,yaitu siklus I dan siklus II, 
siklus I terdiri dari perencanaan, pelaksanaan, pengamatan, refleksi dan siklus kedua juga demikian terdiri dari perencanaan, pelaksanaan, pengamatan dan refleksi

Setting Penelitian

Penelitian ini mengambil lokasi di SD Negeri 016 Bangkinang KotaSesuai dengan standar kompetensi (SK) dan kompetensi dasar (KD) yang telah ditetapkan oleh pusat, maka penelitian ini akan dilaksanakan pada semester genap tahun ajaran 2015/2016. Penelitian ini diperkirakan akan dilaksanakan pada April - Mei 2016

Jumlah populasi dalam penelitian ini adalah seluruh siswa kelas IVdiSD Negeri 016 Bangkinang Kotatahun ajaran 2015/2016 yang berjumlah 20 orang siswa yang terdiri dari 7 orang siswa laki-laki dan 13 orang siswa perempuan.

\section{HASIL DAN PEMBAHASAN}

Hasil belajar diperoleh sebelum tindakan dengan persentase $20 \%$ artinya hasil belajar berada pada interval di bawah 40\%". Siswa yang tuntas hanya 4 orang dari 20 orang siswa, angka ini belum mencapai ketuntasan Kriteria Minimal yaitu 70 yang ditetapkan sekolah. Olehkarena itu penulis perlu dilakukan tindakan perbaikan yaitu pada siklus pertama dan penulis mengharapkan adanya peningkatan hasil belajar siswa setelah dilakukan siklus pertama, dalam penelitian ini penulis menerapkan model pembelajaran Inkuiri.

Setelah dilaksanakan model pembelajaran Inkuiri, hasil belajar siswa meningkat pada siklus I dengan persentase $55.75 \%$.Hal ini, menunjukkan bahwa ada peningkatan dari data sebelum tindakan ke siklus I.

Pada siklus II, hasil belajar siswa pada mata pelajaran Ilmu Pengetahuan Sosial setelah penerapan model pembelajaran Inkuiridengan persentase $84.9 \%$. Hal ini, menunjukkan bahwa ada peningkatan dari data sebelum tindakan ke Siklus I kemudian ke Siklus II.

Berdasarkan hasil observasi pada siklus pertama yang menunjukkan bahwa tingkat aktivitas guru pada siklus I pertemuan pertama mencapai persentase 58.25\%" dan pada pertemuan kedua memperoleh persentase $83.33 \%$. Sedangkan hasil pengamatan aktivitas guru pada siklus II pertemuan pertama memperoleh $84.56 \%$, kedua memperoleh $85.45 \%$.

Berdasarkan hasil observasi pada siklus pertama pertemuan pertama yang menunjukkan bahwa tingkat aktivitas siswa hanya mencapai persentase $64 \%$ dan pada pertemuan kedua aktivitas siswa meningkat dengan perolehan persentase $72.14 \%$, Sedangkan hasil pengamatan aktivitas siswa pada siklus II pertemuan pertama terjadi peningkatan yaitu mencapai persentase $84.28 \%$ dan pada pertemuan kedua meningkat dengan perolehan persentase $95.71 \%$.

Berdasarkan tes hasil belajar pada siklus I dengan nilai dengan persentase $70.1 \%$ dan untuk siklus II denganpersentase $84.9 \%$. Selanjutnya hasil belajar siswa yang mengalami kenaikan ada sebanyak 12 orang, selanjutnya untuk nilai yang tetap sebanyak 2 orang dan nilai belajar siswa yang turun sebanyak 4 orang.

Hasil observasi sebelum tindakan hasil belajar siswa diperoleh persentase $55.75 \%$.Kemudian berdasarkan hasil tes pada siklus pertama yang menunjukkan bahwa hasil belajar siswa mencapai persentase $70.1 \%$.Sedangkan pada siklus II terjadi peningkatan dengan peroleh persentase $84.9 \%$ sehingga sudah mencukupi ketuntasan klasikal $80 \%$ didalam penilitian ini.

Keberhasilanini dipengaruhi karena model pembelajaran Inkuiri, karena model pembelajaran ini dapat membuat siswa lebih aktif dan berani bertanya tentang materi yang belum dipahami, siswa dapat kemudahan dalam menerima dan memahami materi yang diajarkan karena terjadi timbal balik antara guru dan siswa, dan siswa berpartisipasi melalui tulisan, serta dengan model pembelajaran ini siswa lebih memahami konsep-konsep dasar materi pelajaran. 


\section{SIMPULAN}

Berdasarkan hasil penelitian tindakan kelas yang telah dilakukan penerapan model pembelajaran Inkuri dikelas IV SD Negeri 016 Bangkinang KotaTahun Pelajaran 2015/2016 dapat disimpulkan:

a. Hasil belajar IPS siswa kelas IV SD Negeri 016 Bangkinang Kotameningkat setelah diterapkan model pembelajaran Inkuiri dilakukan .

b. Setelah mengunakan model pembelajaran Inkuiri dalam pembelajaran IPS keaktifan siswa ternyata juga meningkat.

c. Telah terjadi peningkatan hasil belajar IPS melalui model pembelajaran Inkuiri siswa kelas IV SD Negeri 016 Bangkinang Kota.

Berdasarkan kesimpulan, peneliti menyarankan kepada guru mata pelajaran IPS untuk dapat menerapkan model pembelajaran Inkuiri sebagai salah satu alat perbaikan pembelajaran pada pokok bahasan lain untuk meningkatkan hasil belajar siswa.

Untuk pembaca dapat memberikan masukkan- masukan atau saran yang sifatnya membangun, sedangkan untuk peneliti berikutnya, agar dapat mengembangkan model pembelajaran Inkuiri pada mata pelajaran lainnya

Bagi guru IPS SD Negeri 016 Bangkinang Kota,penerapan model pembelajaran Inkuiri, dapat dijadikan sebagai salah satu alternatif untuk meningkatkan hasil belajar siswa. Bagi sekolah khususnya SD Negeri 016 Bangkinang Kota,PTK ini sebagai contoh atau referensi bagi guru dalam melaksanakan penelitian atau karya ilmiah dimasa yang akan datang.

\section{DAFTAR PUSTAKA}

Ahmadi, Abu. 2005. SBM (Strategi Belajar Mengajar). Bandung: CV. Pustaka Setia.

Departemen Pendidikan dan Kebudayaan. 2002. Kamus Besar Bahasa Indonesia.
Dimyati dan Midjiono, 2006. Belajar dan Pembelajaran, Jakarta: Rineka Cipta.

Djamarah, 2006. Strategi Belajar Mengajar. Jakarta: Rineka Cipta

Eva, Musnelly. 2006. Modul Materi Pembelajaran Strategi Belajar Mengajar (S.M.B) IPS/PKn SD. FKIP.UNRI. Tidak Diterbitkan

Rani. 2009. Penggunaan Metode Inquiri Untuk Meningkatkan hasil Belajar Pkn Pada Siswa Kelas V DI SD Negeri 019 Teluk Bano II Kecamatan Bangko Kabupaten Rokan Hilir. Pekanbaru: UNRI

Kunandar, 2007.Guru Profesional. Jakarta: Rajawali Pers

Mulyasa, E. 2007.Menjadi Guru Profesional Menciptakan Pembelajaran Kreatif dan Menyenangkan. Bandung: Rosda.

Muhibbin, Syah. 1996. Psikologi Pendidikan. Bandung. Remaja rosda karya

Roestiyah. 2001. Strategi Belajar Mengajar. Jakarta: Rineka Cipta

Sanjaya, Wina. 2007. Strategi Pembelajaran BeroriPendidikan. Jakarta: Kencana

Sardiman, A.M, 2004. Interaksi dan Motivasi Belajar Mengajar, Jakarta: PT. Raja Grafindo Persada.

Wahab, Abdul Aziz, 2007. Metode dan Model-Model Mengajar IPS, Bandung: Alfabeta.

Winkel. 2005. Psikologi Pengajaran. Yokyakarta. Media Abadip 